\title{
Wastewater treatment and reuse in Alicante (Spain)
}

\author{
A. Arahuetes \\ Inter-university Institute of Geography, University of Alicante, Spain
}

\begin{abstract}
The treatment of wastewater in the province of Alicante (Spain) has experienced a positive evolution during the last few decades in that it was able to treat the volumes generated by the increasing population and adapt itself to the provisions of the CEE Directive 91/271. The implementation of the network collectors and the wastewater treatment system has meant that the province has been able to treat a total of $119 \mathrm{hm}^{3}$, which means $2.7 \%$ of all the water treated in Spain during 2014. It has also resulted in a large number of plants being built with tertiary treatment, and even more advanced treatments that improve the quality of water with a view to future use. The increase in the quality of treated water occurs because of these improvements and aims not only to preserve the natural environment with appropriate discharges to the regulations, but also to form a model of an integrated water cycle system where reclaimed water can be returned to the system for different applications. Given the water scarcity in the area the ability to reuse this treated water is a key element in ensuring certain water demand as this new resource could be used for urban (street cleaning, watering gardens) or agricultural uses (irrigation) without having to resort to drinking water so lacking in this area. That is why this paper examines and evaluates the situation of wastewater treatment, and the later use of this reclaimed water in the province of Alicante, as this is a clear example in efficiency in the treatment and utilization of wastewater.

Keywords: wastewater, treatment, non-conventional resource, reuse, water cycle, tourism, Alicante.
\end{abstract}




\section{Introduction}

Water, considered ancestrally as an unlimited renewable resource, has acquired, from the second half of the twentieth century, an aspect of a natural, economic and social good, characterized by its limited value and for being limiting as well (Rico et al. [1]). In the Spanish Mediterranean region, water has become a critical resource for the socio-economic development of this area, especially for the tourism and agriculture sector (Hernández [2]), but has also become a problem due to its scarcity. This province has a significant need for water resources, given the scarcity of its own resources due largely to climatic factors (Olcina and Rico [3]). In addition, tourism, a fundamental pillar on the Mediterranean coast, can generate a triplication of the population during the summer holidays. Besides this, an increase in demand due to agricultural development in the area has also been recorded, which, resulting from intensive cultivating systems, has led to an increase in arboreal and vegetable species in the area (Rico and Hernández [4]). This substantially affects the consumption demand and the subsequent treatment of the wastewater generated, so the infrastructure must be tailored for these flow peaks. In order to be able to ensure those new demands we have had to find new sources of supply, such as those called non-conventional resources. Reusing wastewater, after it has been properly treated, is one these new resources. In this way, the effluent from the wastewater treatment plant, which previously was discharged to a channel or to the sea, returns in order to be reintegrated into the hydrosocial cycle.

Water collected in urban agglomerations is called urban wastewater and it stems from the discharges of domestic activity often mixing with commercial, industrial, and agricultural activities, integrated in the urban nucleus, and also storm water (Trapote [5]). Urban wastewater, although it has a more or less stable composition, varies influenced by factors such as eating habits, water consumption, use of cleaning products at home, or on the day of the week or time of day. These differences are critical in order to choose the suitable treatment to use and the future uses for which it is targeted. Each contaminant has a different impact on water and its removal is key, depending on its destination. Technological improvement in treatment systems, especially from an advanced tertiary treatment, by combining ultrafiltration and desalination, has led to an increase in the potential uses of reclaimed water.

The proceedings that could be undertaken to increase the availability of resources are in the treatment and reuse of wastewater in agriculture, urban use (street cleaning, irrigation of parks and gardens) and other uses (golf courses, medians of roads and highways) which most likely has short-term benefits (Rico [6]). Since the last quarter of the last century, a thesis has repeatedly been proposed that the advanced treatment of municipal and industrial wastewater provides a treated water of such quality that should not be wasted, but used for beneficial purposes (Asano [7]). Furthermore, the treatment and reuse of these resources excel in economic and ecological advantages compared to seawater desalination and, despite the cost reduction of the latter technology, the difference between the two solutions is still maintained thanks to 
the simultaneous progress of recycling (Angelakis et al. [8]). Moreover nonconventional resources, like reuse, in this area can help to relieve sociopolitical conflicts generated by the need to bring water from other basins in order to ensure supplies. The development experiencing this new resource has been going on since the late twentieth century, due in part to the fulfillment of the EU directive 91/271/CEE on the treatment of urban wastewater that has been instrumental in the drive to treat wastewater in Spain, whose competences are transferred to the autonomous communities and are also undertaken to treat wastewater before it is discharged or reused.

Through this paper we aim to clarify the developments that have been subjected to water treatment processes which have been going on in recent years in the southeast Spain, and the use of reclaimed water as an alternative resource. After studying the development of wastewater treatment and reuse, the study is exemplified by the case of the city of Alicante.

\section{Evolution and current situation}

One of the main incentives that has made the treatment process evolve is the rule that regulates it. Legislation relating to wastewater treatment has strengthened substantially in recent decades, both in Europe and Spain; these regulations being a boost in implementing systems of wastewater treatment in order to achieve the ecological "well-being" waters within a framework of sustainability.

In Europe, the Water Framework Directive 2000/60/EC, the European Community Directives 271/91/EC and 98/15/EC on sanitation and treatment, are mandatory references for the required quality of the treated water. These standards lay down an imperative timetable, according to which, prior to $31 \mathrm{st}$ December 2005, all the treatment plants would have had to have a secondary treatment for all towns having more than 2,000 equivalent inhabitants (h-e), and over 10,000 (h-e) in coastal areas. The parameter (h-e) is equivalent to 200 litres of wastewater per day, or in contamination, 60 grams of $\mathrm{BOD}_{5}$ (Bio-chemical Oxygen Demand) per day. However, it should be noted that there is still no regulation establishing the minimum quality requirements of providing treated water intended for reuse. A fact that has not been remedied yet in the Water Framework Directive 2000/60/EC by not paying enough attention to nonconventional sources. At the European level, and in compliance with Directive 91/271/CEE, very encouraging levels water treatment are being reached, and non-compliance is being punished by substantial fines.

The treatment of wastewater in the Valencian region has experienced a positive evolution during the last two decades in relation to the degree of population, treated volumes and degree of compliance with EEC Directive 271/91. A turning point was the execution of the Director Plan of Sanitation and Treatment (1992) which, in turn, developed the Law of Sanitation Wastewater of Valencia (Law 2/1992, 26th March), which also involved establishing the Public Entity Wastewater Treatment (EPSAR). In a first phase (1992-1993), actions were put in place in municipalities with more than 10,000 inhabitants, and in a second stage formed in the years to 2005 , actions were focused on correcting the 
problems of purification and sanitation in towns with fewer than 2,000 inhabitants. This also included the construction of small plants in neighborhoods and residential areas on the coast which lacked such a basic service. In both phases, the overall level of treatment most often used was the secondary (biological), and from 2005, a new cycle has promoted tertiary systems, sometimes including desalination, to encourage greater reuse of flow regenerated for agricultural, urban and recreational uses. For financing those projects, Law 2/1992 established sanitation tax returns which are intended to ensure the functioning of the existing treatment facilities and to contribute to the financing of new ones. The amount of the fee is based on the volume of water consumed for urban use (domestic, commercial, industrial) and its calculation can differ depending on the population served and the pollution load generated. For this fee EPSAR entered, in 2014, more than 265 million euro, with the operating costs of sewage treatment plants (148 million euro), construction of new facilities (39 million euro) and other staff costs faced, etc. The average cost of wastewater treatment in the Valencian region during 2014 was $0.34 € / \mathrm{m}^{3}$.

Currently, existing plants are capable of regenerating the wastewater produced by over $6,500,000 \mathrm{~h}$-e, compared to $4,400,000$ in 2000 . Capacity has also increased to reduce the pollutant load, which was favored in 2005 that the sewage eliminate 500,000 tons of sludge in suspension and $92 \%$ of the $\mathrm{DB}_{5}$ (biodegradable organic matter) of treated wastewater. According to the EPSAR [9], responsible for the management and operations of wastewater treatment plants and other facilities, in 2014 the volume of treated wastewater in the Valencian region stood at $419.81 \mathrm{hm}^{3}$ (fig. 1), of which $119.35 \mathrm{hm}^{3}$ correspond to the province of Alicante. Considering the evolution of the volume of water treated, a significant increase has been observed since the early nineties, linked to a real estate boom and the population increase in that time. Although the population has been growing, a downward trend can be observed in recent years, mainly linked to a decrease in consumption of urban water.

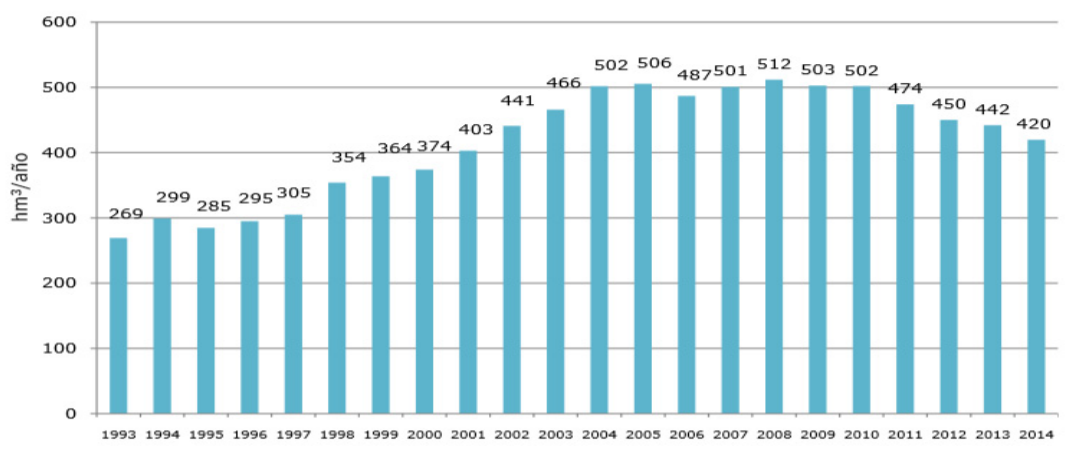

Figure 1: Evolution of treated water in the Valencian region. 


\section{Reusing water}

Direct reuse of reclaimed water is increasingly used internationally and is a widespread practice in Spain, a Mediterranean country with a high variability of availability and water balance deficit (Morales et al. [10]). In this case, reusing water represents an increase in the availability of water in coastal areas where the treated water is discharged into the sea, allowing for the replacement of reclaimed water as drinkable water, leaving this last for uses that require higher quality water and avoiding the discharge of treated water into the river or sea with the environmental implications that entails.

In Spain, the specific legislation governing the use of wastewater is collected in the Royal Decree 1620/2007, which conforms with the legal framework for the reuse of treated water. In this direction, this royal decree defines these resources as "treated wastewater that, in this case, has been subjected to a process of additional or complementary treatment allowing quality to adapt their future intended use". The treatment process required for wastewater to be reused is called "regeneration" and is returning, partially or completely, the level of quality that it used to have before consumption, recovering qualities that make it useful to address certain uses. The qualities of reclaimed water set out in Annex I.A of RD reuse total 14, grouped into five types of use: urban, agricultural, industrial, recreational and environmental. This standard also provides in Chapter II the forbidden uses which are: for human consumption, except in the case of catastrophe; own use in the food industry except for water process and cleaning; use in hospital facilities; filtering for growing shellfish aquaculture; recreational and bathing water; use in cooling towers and evaporative condensers except as provided in this industrial use in the standard; use in fountains and ornamental plates or public interior spaces of public buildings; and any other use that the authorities consider carries health risks or harm to the environment.

From the point of view of management, the use of reclaimed water has been contemplated and promoted by different public statements from municipal ordinances, such as Madrid or Lanzarote, regional management plans or the National Plan for Water Reuse driven by the Ministry of Agriculture, Food and Environment with which it is intended to achieve the reuse of $1,130 \mathrm{hm}^{3}$ of treated water in the last planning cycle which ends in 2015.

In the case of the reuse of treated wastewater, there has been an enormous development of water treatment infrastructures in the Valencia and Murcia regions (Pérez et al. [11] and Rico and Hernández [4]), resizing them in order to increase regenerated flows according to population growth experienced in recent decades. This has allowed that the Segura River Basin to be positioned as the only Spanish watershed where nearly $100 \%$ of wastewater is treated and reused (Olcina and Moltó [12]). This system has already been used in this area for years for optimizing the resource for obtaining water - depending on the degree of treatment which can be used in terms of quality - mainly for irrigation. It also allows better quality water to be reserved such as from conventional sources to urban uses, thus decreasing dependence for example on the waters of the TajoSegura transfer. Therefore, the reuse of reclaimed water is considered to be one 
of the practices best suited with the principles of sustainable development (Seguí [13]), although its use is limited by the rules and the social rejection that occurs for domestic use due to health reasons (Baeza [14] and March et al. [15]).

Alicante has been reusing wastewater for more than three decades in order to satisfy the agricultural demands, by using technological approaches that are pioneers internationally. Different irrigation entities have granted a volume of 66 million $\mathrm{m}^{3} /$ year, while the irrigation of golf courses, highway medians and gardens consume another 4 million $\mathrm{m}^{3} / \mathrm{year}$ (Rico et al. [1]). The most important initiatives for reuse are in the regions of the Vinalopó, Campo de Alicante, Marina Baja and Bajo Segura, where abundant water treatment plants are subjected to the heavy use of wastewater. For example, the general user community of Sax has set as a priority in its activities the preservation of water, including the full use of all the resources provided by the treatment plant of Villena, which in turn regenerates wastewater for the municipalities of $\mathrm{La}$ Canada and Campo de Mirra. It also assumes a prototypical hydraulic complex built in 1980 by the IRYDA in the Middle Vinalopó and Campo de Alicante, which can be raised by several driving systems adding up to 400 meters. The reclaimed waters of the treatment plant of Rincón de León (Alicante) goes to areas of irrigation in Agost and Monforte del Cid, with costs near to $0.18 € / \mathrm{m}^{3}$ that are entirely assumed by the farmers. A much more favorable agreement exists for the irrigators of Marina Baja, thanks to the systems of existing wastewater reuse in the region, based on the transfer of clean water in exchange for residual wastewater at zero cost benefit. The agreement was decisive and an imaginative technical solution, consisting of the construction of the treatment plant of Benidorm in the foothills of Sierra Helada, at 135 meters above sea level. This allows injecting water without pumping or using elevations in the pipes of the Irrigation Community Canal Bajo del Algar to irrigate 2,400 ha of citrus and persimmons. In return, the Consorcio de Aguas de la Marina Baja (1978) is benefitting by of the transfer of clean water from the Guadalest-Algar system, which is vital to maintain the supply of drinkable water in tourist resorts such as Benidorm, Villajoyosa and Alfaz del Pi (Rico et al. [16]).

\section{Case studies: Alicante}

The city of Alicante forms a very representative model in terms of wastewater treatment and reuse because, due to its location, the city has had to implement its capacity for water treatment and reuse in order to satisfy the demands of both urban and agricultural uses. It has two treatment plants called Monte Orgegia and Rincón de León which are responsible for treating over 18,000,000 $\mathrm{m}^{3} /$ year received (fig. 2).

The treatment plant of Monte Orgegia serves the northern part of the municipality of Alicante and the towns of San Juan de Alicante, Mutxamiel and Campello. It is a conventional treatment plant using activated sludge and anaerobic digestion. It has a capacity of $60,000 \mathrm{~m}^{3} /$ day, divided into the primary treatment and secondary treatment in two parallel lines. Line A has a capacity of $36,000 \mathrm{~m}^{3} /$ day and it was recently executed during the enlargement of the 


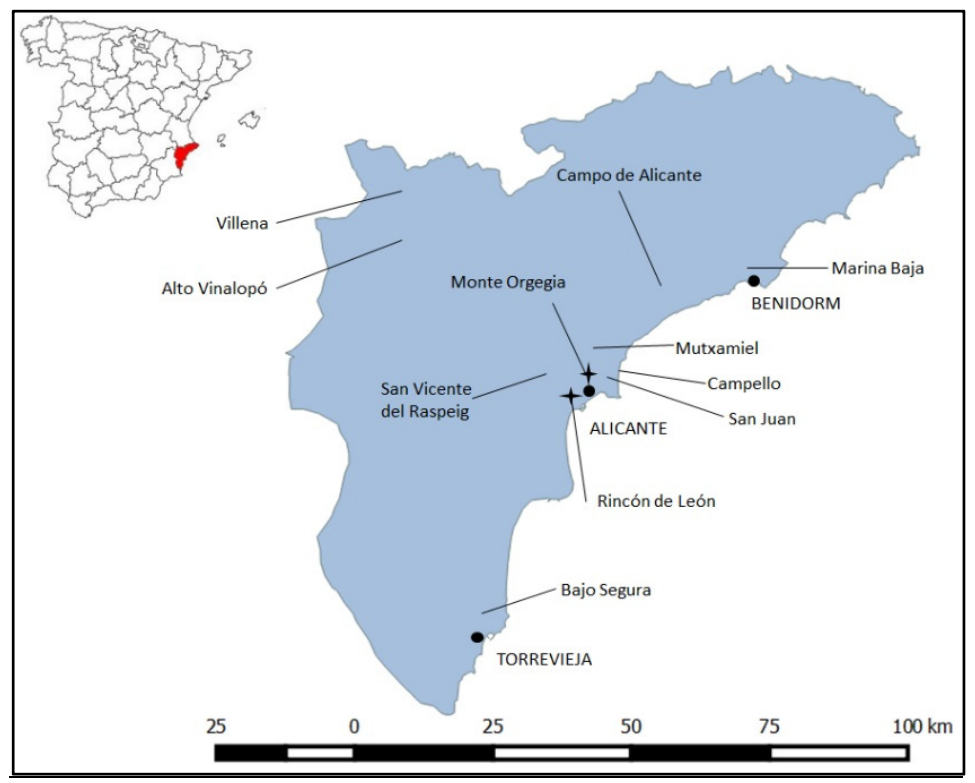

Figure 2: Location.

facilities in 2006 . Line B is able to treat $24,000 \mathrm{~m}^{3} /$ day, which corresponds to the capacity of the former plant, which opened in 1989. The facilities of Monte Orgegia essentially comprise the following process steps: water line, sludge line and gas line. The raw water entering the plant is driven by the pumping stations of Condomina and the Pla.

The wastewater treatment plant of Rincón de León collects water from the south of the town of Alicante and the town of San Vicente del Raspeig. It is a conventional treatment plant using activated sludge and anaerobic digestion. It has a treatment capacity of $75,000 \mathrm{~m}^{3} /$ day that in the primary decanted off and the biological process is divided into two lines: Line A of $50,000 \mathrm{~m}^{3} /$ day, corresponding to the last enlargement in 2011; and line B 25,000 $\mathrm{m}^{3} /$ day corresponding to the old plant opened in 1982. In order to allow treatment of desalination and reuse of treated water flows input to the plant were subdivided according to their different salinity. Anaerobic sludge stabilization in this plant has resulted in the production of biogas. This fuel is used for heating the sludge digestion and mainly for the production of electricity. It has two cogeneration engines with an average power output of $2 \mathrm{MWh} / \mathrm{year}$. This energy is fully utilized within the facilities (consumption).

Plá drive is connected to both treatment plants. In this way wastewater from a part of the city can be pumped to the treatment plant that is receiving less flow at the time. This model is very useful especially during holiday periods considering that Monte Orgegia plant that receives water from the coast that increased its flow with the arrival of tourism and is not able to treat the entire flow received. The following chart shows the flows treated in recent years for the two plants 
that treat wastewater from the city of Alicante. By analyzing data from this graph with the plant Monte Orgegia (fig. 3), variations are observed in the treated flows due not only to variable flow rates received from the pumping Pla, but also other factors, such as the anomalous data 2006 matching with the expansion of the plant, a consequent increase in flow rate given the new treatment capacity, and finally a decrease probably due to decreases in the urban water consumption. That is why the data from 2000 and 2013 hardly differ, even though the plant now has more capacity and the population has increased in this period by more than 55,000 inhabitants (INE [17]).

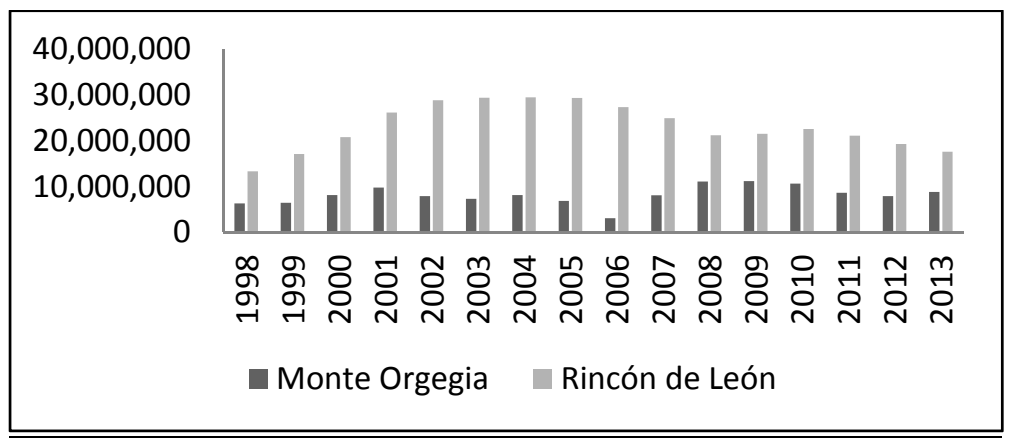

Figure 3: Volumes of wastewater treated in Monte Orgegia and Rincón de León.

The need to improve water quality for certain agricultural use led to the construction of the regeneration facility of treated water in Rincón de León (IRAD). The maximum production of desalinated water is $25,600 \mathrm{~m}^{3} /$ day plus an additional $13,000 \mathrm{~m}^{3} /$ day of ultra-filtered water. Four lines use reverse osmosis; this way the high content of salinity $(2,800 \mu \mathrm{s} / \mathrm{cm})$ of the wastewater that reaches the treatment plant is reduced to $600 \mu \mathrm{s} / \mathrm{cm}$, thereby obtaining a high quality resource for watering all sorts of agricultural production. This facility is owned by EPSAR and reclaimed water is available on-demand from the communities of irrigators Agricoop and Aralvi for the Campo de Alicante and Middle Vinalopó, and another 7,000 ha of the Irrigation Community of Levante in the town of Elche, at a cost not exceeding $0.10 € / \mathrm{m}^{3}$. These irrigation communities have the ability to mix the effluent deposits in each of the processes provided by IRAD with water of a certain quality depending on the needs of the type of crop.

Table 1 lists the reclaimed water intended for agricultural and urban reuse of the various treatment plants of Alicante. The reuse of water from the Rincón de León plant is primarily intended for agricultural use, while water from the Monte Orgegia plant spreads its flow between agricultural and urban use. A clear increase of these flows can be appreciated, although all the water treated is yet intended for other new uses. 
Table 1: $\quad$ Reused flows.

\begin{tabular}{|l|c|c|c|c|c|c|}
\cline { 2 - 7 } \multicolumn{1}{c|}{} & \multicolumn{4}{c|}{ Rincón de León } & \multicolumn{2}{c|}{ Monte Orgegia } \\
\hline \multirow{2}{*}{ YEAR } & \multicolumn{2}{|c|}{ Agricultural Irrigation } & $\begin{array}{c}\text { TOTAL } \\
\text { IRRIGATION }\end{array}$ & URBAN USE & $\begin{array}{c}\text { TOTAL } \\
\text { IRRIGATION }\end{array}$ & URBAN USE \\
\cline { 2 - 7 } & AGRICOOP & ARALVI & IRIG. & \\
\hline $\mathbf{2 0 0 3}$ & 2.550 .176 & 3.568 .980 & 6.119 .156 & 38.731 & 402.970 & 43.668 \\
\hline $\mathbf{2 0 0 4}$ & 2.682 .781 & 3.158 .038 & 5.840 .819 & 27.894 & 385.700 & 66.831 \\
\hline $\mathbf{2 0 0 5}$ & 3.419 .429 & 3.818 .917 & 7.238 .346 & 19.595 & 1.171 .217 & 156.348 \\
\hline $\mathbf{2 0 0 6}$ & 4.402 .163 & 4.047 .552 & 8.449 .715 & 29.130 & 1.421 .583 & 250.219 \\
\hline $\mathbf{2 0 0 7}$ & 3.487 .785 & 3.238 .521 & 6.726 .306 & 19.540 & 946.813 & 412.613 \\
\hline $\mathbf{2 0 0 8}$ & 3.620 .018 & 4.041 .599 & 7.661 .617 & 44.928 & 1.040 .963 & 592.022 \\
\hline $\mathbf{2 0 0 9}$ & 3.235 .427 & 2.962 .306 & 6.197 .733 & 49.845 & 704.867 & 631.260 \\
\hline $\mathbf{2 0 1 0}$ & 2.420 .826 & 2.067 .212 & 4.488 .038 & 45.354 & 565.812 & 750.946 \\
\hline $\mathbf{2 0 1 1}$ & 2.920 .812 & 2.613 .934 & 5.534 .746 & 37.407 & 761.206 & 858.902 \\
\hline $\mathbf{2 0 1 2}$ & 3.467 .576 & 3.063 .073 & 6.530 .649 & 40.850 & 1.006 .370 & 903.305 \\
\hline $\mathbf{2 0 1 3}$ & 3.647 .780 & 1.968 .620 & 5.616 .400 & 53.703 & 1.031 .635 & 996.360 \\
\hline
\end{tabular}

As has been said before, although not using all the reclaimed water that could be used, which in recent years has reached approximately $25 \%$ of the treated water of Alicante (fig. 4), the city is a pioneer in this field and has a Director Plan for Water Reuse (2002-2003) that is promoting the construction of this dual network of reused water. The water company of the city Aguas Municipalizadas de Alicante (AMAEM [18]), is responsible for implementing this plan, by which more than $70 \%$ of the green areas of the city are watered with reclaimed water.

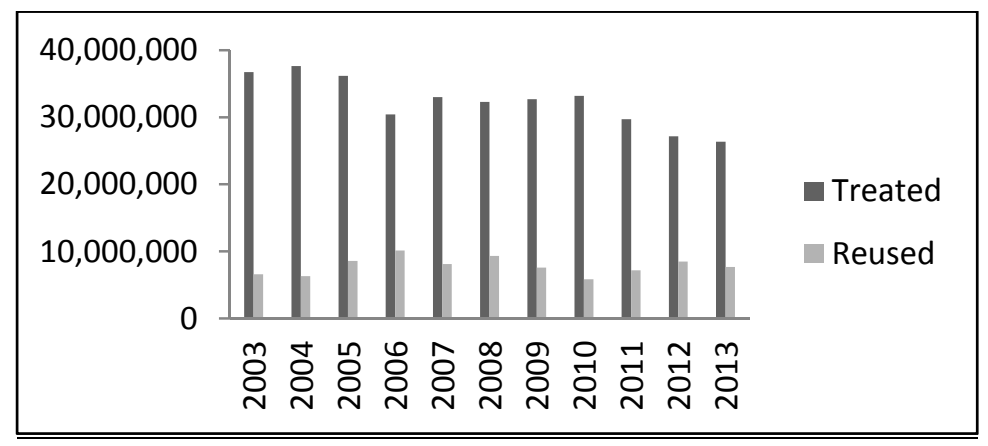

Figure 4: Treated and reused water in Alicante.

Other innovations in this area are the antipollution deposits. This region of Spain suffers, usually in the fall, episodes of high-intensity rainfall in a short amount of time. This generates a large quantity of runoff water that ends up in the sewage system where treatment plants do not have time to treat the water from these avenues. These waters also drag pollution from the streets. In order to solve this problem and be able to treat and use all the water, two processes have to be undertaken. Firstly the antipollution deposit of San Gabriel, built in 2011 and capable of storing $60,000 \mathrm{~m}^{3}$. And secondly the flooded park of La Marjal, opened in 2015 with a storage capacity of $45,000 \mathrm{~m}^{3}$. This park stands out for its environmental sustainability and is a highly acclaimed urban solution that works as a park during the year and becomes a lake thanks to a system of collectors that 
collect water from the street of the beach of San Juan during the floods, to further pump this water to the treatment plant. This way the treatment plan would be able to treat all the rainwater and it is not wasted. Through these measures, it seeks to promote the use of this alternative resource against the consumption of drinking water to meet certain needs. In addition, the process of reuse of reclaimed water is an economic, energy and environmental savings and that has tripled in recent years the area devoted to parks and green spaces (Hidraqua [19]).

\section{Conclusions}

In a scenario of rainfall shortage, a hydric deficit derived from climate change and its effects in the Mediterranean areas, an evaluation and eventual mobilization of all available water resources stands as a social priority and territorial objective. Moreover, in this area with growing calls for both urban and irrigation water, demands that have grown linked to urban and population development during the last few decades. In this urban-tourism sector, of great importance for the eastern coast of the Iberian Peninsula, conventional resources like water from reservoirs, aquifers and transfers are in principle the most exposed to periods of drought. In comparison, the use of unconventional resources, as the reuse of reclaimed water, is presented as an alternative to adapt to scarce and erratic rainfall. That is why the wastewater treatment systems, favored by the legislation that regulates them, have suffered a great evolution overlooking to obtaining better quality water for both discharge and subsequent reuse. Once the desired quality is reached, this reclaimed water has been used for both agricultural irrigation and in some urban uses such as street cleaning or the irrigation of green areas, replacing volumes of water from conventional sources that can now be used in primary needs such as ensuring the supply.

In the Valencian region, in 2015 , of $419.73 \mathrm{hm}^{3}$ of treated water, only $34.73 \%$ is reused. Of these reused resources, $91.87 \%$ is intended for agricultural use and only $6.75 \%$ for urban use. Regarding indirect reuse (discharged into channels) $\left(118.42 \mathrm{Hm}^{3}\right)$ represents $28.21 \%$ of the total treated water. By provinces, Alicante is the region with most water reuse $(46.26 \%)$, second is Valencia (34.86\%) and Castellón with only $7.97 \%$. This result is logical, considering that Alicante is the province of the Valencian region that has less conventional resources, and is therefore the one that uses more alternative resources. In this regard, the Valencian region shows it is missing an easily usable application that may demand this type of non-conventional water resource. In addition, if it is bound to the cost of production of this resource that it is of $0.34 € / \mathrm{m}^{3}$ (five times cheaper than drinking water), it is therefore being left out as an alternative source from an environmental and economic term. More so, considering the current economic situation that can benefit in reducing costs through the use of this resource. 


\section{Acknowledgements}

This paper is the result of a pre-doctoral fellowship of the Researcher Training National Program for Scientific Research, Development and Technological Innovation Research (FPI) and is inserted in the research project "Construction and water metabolism on the coast of Alicante: trend analysis for the period 2000-2010" (CSO2012-36997-CO2-02) funded by the Ministry of Economy and Finance.

\section{References}

[1] Rico, A. M., Olcina, J., Paños, V., Baños, C. Depuración, desalación y reutilización de aguas en España. Oikos-Tan: Vilasar de Mar, 255 p., 1998.

[2] Hernández, M. Análisis de los procesos de transformación territoriales en la provincia de Alicante (1985-2011) y su incidencia en el recurso hídrico a través del estudio bibliográfico. Documents d'Anàlisi Geográfica, 59(1), pp. 105-136, 2013.

[3] Olcina, J., Rico, A. M. Recursos de agua "no convencionales" en España. Depuración y desalación. Los usos del agua en España, eds. Gil, A. and Morales, A., Instituto Universitario de Geografía and Caja de Ahorros del Mediterraneo, Alicante, pp. 203-252, 1999.

[4] Rico, A. M., Hernández, M. Ordenación del territorio, escasez de recursos hídricos, competencia de usos e intensificación de las demandas urbanoturísticas en la Comunidad Valenciana. Documents d'Anàlisi Geográfica, 51, pp. 79-109, 2008.

[5] Trapote, A. Depuración de las aguas residuales urbanas. Publicaciones Universidad de Alicante, Alicante, 429 p., 2011.

[6] Rico, A. M. Depuración y reutilización de aguas residuales en el litoral alicantino. Papeles de Geografia, 23-24, pp. 245-261, 1996.

[7] Asano, T. La recuperación de las aguas residuales municipales como nuevo recurso hídrico. Jornadas internacionales Agua Horizonte 2005, Murcia, 1997.

[8] Angelakis, A., Marecos do Monte, M. H. F., Bontoux, L., Asano, T. The status of wastewater reuse practice in the Mediterranean basin. Water Res, 33(10), pp. 2.201-2.217, 1999.

[9] Entidad Pública de Saneamiento de Aguas Residuales (EPSAR), 2015, http://www.epsar.gva.es/sanejament/index.aspx

[10] Morales, A., Olcina, J., Rico, A. M. Diferentes percepciones de la sequía en España: adaptación, catastrofismo e intentos de corrección. Investigaciones Geográficas, 23, pp. 5-46, 2000.

[11] Pérez, A, Gil, E., Gómez, J. M. Las aguas residuales regeneradas como recurso para los regadíos de la Demarcación Hidrográfica del Segura (España). Boletín de la Asociación de Geógrafos Españoles, 64, pp. 151$175,2014$. 
[12] Olcina, J., Moltó, E. Recursos de agua no convencionales en Españo: estado de la cuestión, 2010. Investigaciones Geográficas, 51, pp. 131-163, 2010.

[13] Seguí, L. A. Sistemas de regeneración y reutilización de aguas residuales. Metodología para el análisis técnico-económico y casos. Doctoral thesis, Universidad Politécnica de Catalunya, Departament d'Enginyería Agroalimentària i Biotecnología, 2004.

[14] Baeza, J. Reutilización de aguas residuales para riego. Trabajo Fin de Máster en Gestión Sostenible y Tecnologías del Agua. Universidad de Alicante, 2005.

[15] March, H., Hernández, M., Saurí, D. Percepción de recursos convencionales y no convencionales en áreas sujetas a estrés hídrico: el caso de Alicante. Revista de Geografia Norte Grande, 60, pp. 153-172, 2015.

[16] Rico, A. M., Arahuetes, A., Morote, A. F. Depuración y reutilización de aguas residuales regeneradas en las regiones de Murcia y Valencia. Paisaje, cultura territorial y vivencia de la Geografia. Libro Homenaje al profesor Alfredo Morales Gil, eds. Vera Rebolledo, J. F., Olcina, J., Hernández, M. Ediciones de la Universidad de Alicante, pp. 1169-1202, 2016.

[17] Instituto Nacional de Estadística (INE), 2015, http://www.ine.es/

[18] Aguas Municipalizadas de Alicante (AMAEM), 2015, http://www.aguasdealicante.es/Inicio/

[19] Hidraqua, 2015, http://www.hidraqua.es/es 